\title{
ANALISIS KESALAHAN BUKU MATEMATIKA MATERI RELASI DAN FUNGSI KELAS VIII SERTA ALTERNATIF PENYELESAIANNYA
}

\author{
Abdur Rohim \\ Pendidikan Matematika, FKIP, Universitas Islam Darul 'ulum Lamongan \\ rohim@unisda.ac.id
}

\begin{abstract}
Abstrak
Salah satu aspek kurikulum 2013 yang perlu disempurnakan adalah buku bacaan. Buku bacaan berfungsi untuk menunjang guru dalam mengantarkan modul serta bisa menunjang siswa dalam mendukung modul yang di informasikan oleh guru. Kenyataan di lapangan, guru enggan menggunakan buku bacaan matematika siswa termasuk buku matematika kelas 8 semester I edisi perbaikan. Hal ini dikarenakan masih ada beberapa kesalahan dan juga buku masih sulit dipahami oleh sebagian siswa. Tujuan dari riset ini merupakan untuk menganalisis terdapatnya kesalahan yang ada pada buku matematika siswa kelas 8 pokok bahasan relasi \& fungsi. Riset ini termasuk riset kualitatif dengan rancangan penelitian deskriptif. Keabsahan data memakai triangulasi data dan kecukupan referensial. Hasil riset menunjukan bahwa masih terdapat 6 kesalahan konsep, 2 kesalahan gambar dan 15 kesalahan penulisan. Dari temuan ini, dapat dikatakan bahwa mutu buku ini belum optimal serta butuh terdapatnya revisi sehingga sejalan dengan tujuan dari pembuatan buku.
\end{abstract}

Kata Kunci: Analisis, buku, fungsi, kesalahan, relasi

\begin{abstract}
One aspect of the 2013 curriculum that needs to be improved is textbooks. Textbooks play a role in helping teachers deliver material and can assist students in supporting the material presented by the teacher. The reality in the field is that teachers are reluctant to use students' mathematics textbooks including the revised edition of class 8 semesters I mathematics books. This is because there are still some errors and also books are still difficult for some students to understand. The purpose of this study was to analyze the errors contained in the mathematics books of class viii students regarding relations and functions. This research is a qualitative research using a descriptive research design. The validity of the data used data triangulation and referential adequacy. The results showed that there were still 6 concept errors, 2 image errors and 15 writing errors. From these findings, it can be said that the quality of this book is not yet optimal and that there is a need for improvement so that it fits the original purpose of making the book.
\end{abstract}

Keywords: Analysis, books, functions, errors, relations 


\section{PENDAHULUAN}

Mutu pendidikan dipengaruhi oleh beberapa aspek, termasuk mutu pengajaran pendidikan pengajaran, mutu belajar siswa dan fasilitas pendidikan. Salah satu fasilitas pendidikan adalah buku bacaan. (Kemendikbud, 2013) Buku-buku yang dipakai di sekolah sudah diatur pada kemendikbud No. 2 tahun 2008. Salah satunya adalah buku bacaan pelajaran, buku bacaan pelajaran merupakan buku referensi yang dibutuhkan oleh sekolah yang berisi materi pembelajaran untuk meningkatkan iman dan takwa, ilmu dan kepribadian, kemampuan penguasaan iptek, kemampuan fisik serta kesehatan, keahlian estetis, yang dirancang bersumber pada Standar Nasional Pembelajaran. Buku bacaan ini disebut juga buku paket (Sitepu, 2012: 8).

buku paket ialah salah satu aspek yang berarti dalam aktivitas pembelajaran. Buku paket menunjang siswa dalam pembelajaran secara mandiri. Buku paket berfungsi untuk membantu pendidik dalam mengantarkan modul dan bisa membantu peserta didik dalam mendukung modul yang di informasikan oleh pendidik. Briton (dalam UM, W. D. P., 2020: 2) mengatakan bahwa buku paket matematika harusnya bisa: (a) tingkatkan keefektifan belajar, (b) memacu serta memudahkan data, serta (c) tingkatkan efisiensi penerapan belajar. Nasution (Prastowo, 2013: 169) menerangkan jika buku bacaan mempunyai guna selaku bahan rujukan ataupun bahan referensi oleh partisipan didik, selaku bahan penilaian, selaku perlengkapan bantu pengajar dalam melakukan kurikulum, selaku salah satu penentu tata cara ataupun metode pengajaran yang hendak digunakan pendidik, selaku fasilitas guna tingkatkan karier serta jabatan.

Kenyataan di Lapangan, buku Matematika yang tersebar, isinya mayoritas hanya merombak dari buku yang sudah ada ataupun rujukan yang telah lama (Susanto, 2013: 3). Perihal ini dapat menjadikan pengetahuan siswa tidak berkembang dengan baik sebab materinya yang konstan. Sepatutnya isi buku pelajaran berpedoman pada kurikulum serta Standart Pembelajaran Nasional. Susanto (2013) mengatakan terdapat 5 kelemahan mengenai buku paket yang tersebar dikala ini antara lain dari segi isi, bahasa, desain grafis, metodologi penyusunan serta strategi indexing. Di sekolah, buku matematika 
siswa kurikulum k13 tidak sering digunakan dengan bermacam alibi. Terdapat pula yang memakai buku ini namun dengan catatan tertentu. Perihal ini menjadikan banyak persoalan tentang buku tersebut oleh periset.

Hasil penelitian yang diungkapkan Valentino (2015) dalam penelitiannya adalah terdapat kesalahan yang terkait dengan fakta dan konsep pada pokok bahasan Relasi dan Fungsi. Kesalahan yang terkait dengan fakta termuat pada halaman 80 (terkait keanggotaan variabel $\mathrm{x}$ ), halaman 92 (terkait syarat $\mathrm{x}$ ). Kesalahan yang terkait dengan konsep terdapat pada halaman 87-89 (terkait relasi). Kesalahan tersebut ada yang sudah direvisi dan ada yang belum direvisi pada buku Matematika siswa kelas viii edisi revisi 2017. Supaya tidak terjalin miskomunikasi oleh pembaca, riset ini dilakukan dengan tujuan untuk mengenali terdapat tidaknya kesalahan yang terdapat dalam buku matematika pokok bahasan relasi dan fungsi kelas 8 semester I kurikulum 2013 edisi perbaikan 2017. Ada pula tipe kesalahan dapat dilihat di Tabel 1. Setelah itu kesalahan yang muncul, diidentifikasi serta diperbaiki, sehingga konten buku sesuai dengan fungsi pembuatan buku itu
Tabel 1. Jenis jenis kesalahan dan indikatornya

\begin{tabular}{|c|c|c|}
\hline \begin{tabular}{|c|} 
Jenis- \\
jenis \\
kesalahan
\end{tabular} & Pengertian & Indikator \\
\hline $\begin{array}{c}\text { Kesalahan } \\
\text { konsep }\end{array}$ & $\begin{array}{l}\text { kesalahan } \\
\text { penalaran dari } \\
\text { kebenaran } \\
\text { sebelumnya }\end{array}$ & $\begin{array}{l}\text { apabila } \\
\text { ditemukan } \\
\text { kesalahan } \\
\text { penalaran dari } \\
\text { penalaran } \\
\text { sebelumnya. }\end{array}$ \\
\hline $\begin{array}{l}\text { Kesalahan } \\
\text { komputasi }\end{array}$ & $\begin{array}{l}\text { kesalahan } \\
\text { berbentuk } \\
\text { perhitungan } \\
\text { dalam } \\
\text { menuntaskan } \\
\text { permasalahan } \\
\text { matematika }\end{array}$ & $\begin{array}{l}\text { apabila } \\
\text { ditemukan } \\
\text { kesalahan } \\
\text { dalam } \\
\text { perhitungan } \\
\text { menyelesaikan } \\
\text { soal }\end{array}$ \\
\hline $\begin{array}{c}\text { Kesalahan } \\
\text { gambar }\end{array}$ & $\begin{array}{l}\text { Kesalahan } \\
\text { dalam } \\
\text { menggambarkan } \\
\text { konsep beserta } \\
\text { gambar }\end{array}$ & $\begin{array}{l}\text { apabila } \\
\text { ditemukan } \\
\text { objek yang } \\
\text { tidak sesuai } \\
\text { dengan } \\
\text { konsep }\end{array}$ \\
\hline $\begin{array}{l}\text { Kesalahan } \\
\text { penulisan }\end{array}$ & $\begin{array}{l}\text { kesalahan dalam } \\
\text { penyusunan } \\
\text { simbol termasuk } \\
\text { penempatan, } \\
\text { dimensi, } \\
\text { kekonsistenan } \\
\text { dalam memakai } \\
\text { simbol serta } \\
\text { kekurangan } \\
\text { ataupun } \\
\text { kelebihan dalam } \\
\text { menulis simbol } \\
\text { dan kesalahan } \\
\text { dalam wujud } \\
\text { lain yang } \\
\text { menyebabkan } \\
\text { simbol diartikan } \\
\text { lain dari fungsi } \\
\text { utamanya }\end{array}$ & $\begin{array}{l}\text { apabila } \\
\text { ditemui } \\
\text { simbol yang } \\
\text { berbeda } \\
\text { dengan } \\
\text { konsep, } \\
\text { berbeda } \\
\text { dengan } \\
\text { penerapan } \\
\text { serta jauh dari } \\
\text { apa yang } \\
\text { diartikan }\end{array}$ \\
\hline
\end{tabular}


Jenis riset ini adalah riset kualitatif dengan menggunakan rancangan penelitian deskriptif. Penelitian ini dilaksanakan selama bulan November 2020. Data utama dalam riset ini ialah buku matematika siswa kelas 8 semester I edisi revisi 2017 materi Relasi dan Fungsi terbitan Kemendikbud, dengan jumlah halaman 41 Halaman (halaman 76-116) (As'ari dkk, 2017). Data diperoleh dengan membaca, meneliti, mengamati, menganalisa setiap halaman pada buku matematika siswa kelas 8 pokok bahasan Relasi dan Fungsi. Jika menemukan kesalahan, maka akan ditulis dalam kartu data dilanjutkan dengan mengkategorikan bersumber pada klasifikasinya. Keabsahan data memakai triangulasi data dan kecukupan referensial.

\section{HASIL DAN PEMBAHASAN}

Hasil dan pembahasan mengenai analisis kesalahan buku matematika materi Relasi dan Fungsi kelas viii semester 1 terbitan Kementerian Pendidikan dan Kebudayaan Republik Indonesia edisi revisi 2017 adalah sebagai berikut.

a. Kesalahan Konsep

Kesalahan Konsep yang pertama adalah pada halaman 73 yaitu tentang peta konsep (Gambar 1a). Peta konsep yang dibuat tidak sejalan dengan isi materi yang disajikan. Sebelumnya pada peta konsep terbaca penyelesaian dari relasi dan fungsi bisa melalui 6 opsi, yaitu diagram panah, diagram kartesius, pasangan berurutan, tabel, grafik dan persamaan. Sedangkan dalam penjelasan materinya adalah penyajian Relasi ada 3, yaitu diagram panah, diagram kartesius dan pasangan berurutan. Sementara penyajian Fungsi ada 5, yaitu diagram panah, diagram kartesius (grafik), pasangan berurutan, tabel dan persamaan

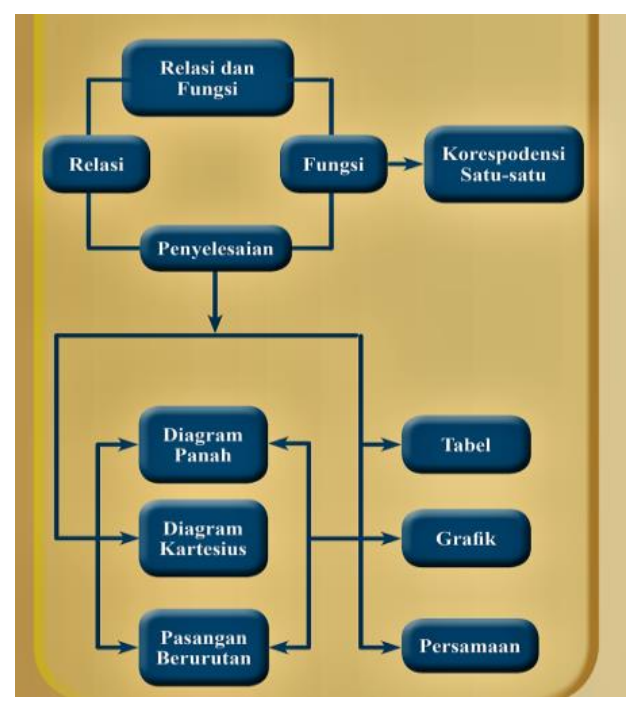

(a) 


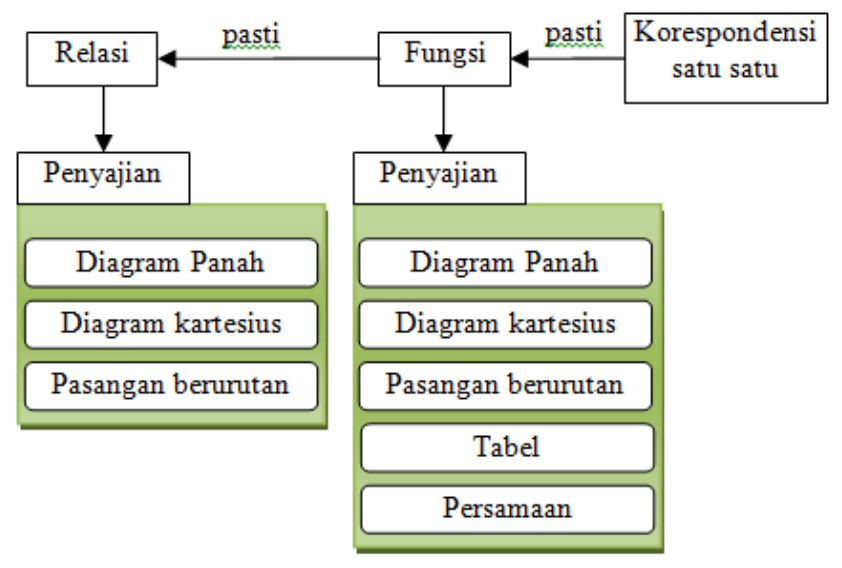

(b)

Gambar 1. (a) Kesalahan Peta Konsep

(b) Alternatif Penyelesian Peta Konsep

Kesalahan konsep kedua terdapat pada halaman 80 terkait relasi (Gambar 2). Diagram panah yang digambarkan tidak sesuai dengan pengertian relasi pada halaman 100 . Sementara pada diagram panah tersebut tidak ada aturan yang menghubungkan kedua himpunan.
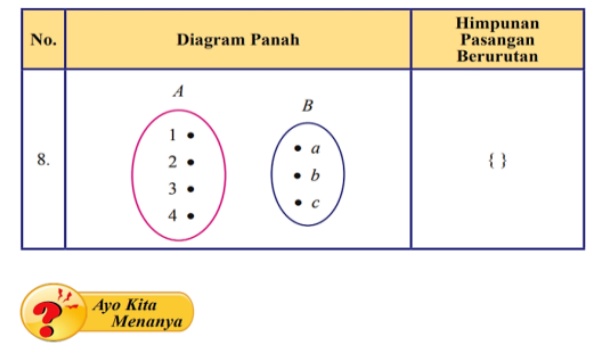

Terkait dengan fokus perhatian pada Tabel 3.1, coba buatlah pertanyaan yang memuat kata-kata berikut: "aturan" atau "relasi"

Contoh pertanyaan

1. Mengapa semua contoh pada Tabel 3.1 dikatakan relasi?

Gambar 2. Kesalahan Konsep Relasi

pada Diagram Panah

Kesalahan konsep yang ketiga, yaitu pada halaman 83 nomor 8 terkait contoh Relasi (Gambar 3). Pada halaman 100, didefinisikan Relasi merupakan ketentuan yang menghubungkan elemen-elemen dua himpunan. Sementara pada contoh nomor 8 tidak ada aturan yang menghubungkan anggota dari masing masing himpunan. Sehingga, alternative penyelesaian dari kesalahan ini adalah dengan menghapus contoh relasi nomor 8 .

Tabel 3.3 Contoh relasi dan bukan relasi

\begin{tabular}{|l|l|}
\hline \multicolumn{1}{|c|}{ Contoh Relasi } & \multicolumn{1}{c|}{ Contoh Bukan Relasi } \\
\hline 1. $\{(1, a) ;(2, a) ;(3, a) ;(4, a)\}$ & 1. $\{(1, d) ;(2,2)\}$ \\
2. $\{(1, a) ;(1, b) ;(1, c)\}$ & 2. $\{(5, a)\}$ \\
3. $\{(1, a) ;(2, c)\}$ & 3. $\{(1,1) ;(2,2) ;(3,3) ;(4,4)\}$ \\
4. $\{(3, b) ;(3, c) ;(4, c)\}$ & 4. $\{(a, a) ;(b, b) ;(c, a) ;(c, c)\}$ \\
5. $\{(2, c) ;(3, c) ;(4, b) ;(4, c)\}$ & 5. $\{(1,2) ;(3,4) ;(4,5)\}$ \\
6. $\{(4, a) ;(4, b) ;(4, c)\}$ & 6. $\{(a, 1) ;(b, 1) ;(c, 3) ;(d, 4)\}$ \\
7. $\{(2, b)\}$ & 7. $\{(5, a) ;(6, b) ;(7, b) ;(8, c) ;(9, c)\}$ \\
8. \{\} & 8. $\{(1, d) ;(2, e) ;(3, f)\}$ \\
\hline
\end{tabular}

Gambar 3. Kesalahan Konsep Contoh Relasi

Kesalahan konsep keempat terdapat pada halaman 86 soal nomor 4 (Gambar 4). Himpunan A adalah Himpunan nama Negara, tetapi didalamnya terdapat Jakarta. Sedangkan himpunan B adalah himpunan nama kota, tetapi didalamnya terdapat Indonesia. Alternative dari kesalahan ini adalah dengan menukarkan Jakarta di elemen himpunan A dengan Indonesia di elemen himpunan B. 


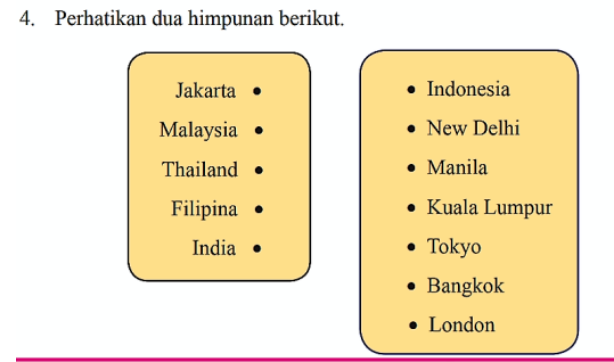

Gambar 4. Kesalahan Konsep Anggota Himpunan

Kesalahan konsep kelima terdapat pada halaman 98 dan 99 (Gambar 5), yaitu terkait contoh bukan fungsi. Pada nomor 8 disebutkan contoh bukan fungsi yaitu $\{(1, b), \quad(2, a), \quad(3, b)\} . \quad$ Padahal $\{(1, b),(2, a),(3, b)\}$ adalah contoh suatu fungsi. Alternative penyelesainnya adalah mengganti $\{(1, b),(2, a),(3, b)\}$ dengan $\{(1, b),(2, a),(2, b)\}$.

Tabel 3.5 Contoh fungsi dan bukan fungsi

\begin{tabular}{|c|l|}
\hline Contoh Fungsi & \multicolumn{1}{|c|}{ Contoh Bukan Fungsi } \\
\hline 1. $\{(1, a),(2, a),(3, a)\}$ & 1. $\{(1, a),(2, a),(2, b)\}$ \\
2. $\{(1, b),(2, b),(3, b)\}$ & 2. $\{(1, b),(2, a),(2, b)\}$ \\
3. $\{(1, a),(2, a),(3, b)\}$ & 3. $\{(1, a),(1, b),(3, b)\}$ \\
4. $\{(1, a),(2, b),(3, a)\}$ & 4. $\{(2, a),(2, b),(3, a)\}$ \\
5. $\{(1, a),(2, b),(3, b)\}$ & 5. $\{(2, a),(2, b),(2, c)\}$ \\
6. $\{(1, b),(2, a),(3, a)\}$ & 6. $\{(1, b),(2, a),(2, b)\}$ \\
7. $\{(1, b),(2, b),(3, a)\}$ & 7. $\{(3, a),(3, b),(3, c)\}$ \\
8. $\{(1, b),(2, a),(3, b)\}$ & 8. $\{(1, b),(2, a),(3, b)\}$
\end{tabular}

(a)

\begin{tabular}{|c|c|c|c|}
\hline No. & $\begin{array}{c}\text { Contoh Bukan } \\
\text { Fungsi }\end{array}$ & $\begin{array}{c}\text { Apakah setiap } \\
\text { anggota } \boldsymbol{A} \text { selalu } \\
\text { dipasangkan dengan } \\
\text { suatu anggota } B ? \\
\text { (Ya/Tidak) }\end{array}$ & $\begin{array}{c}\text { Apakah pasangan } \\
\text { dari setiap anggota } \\
\text { domain hanya satu } \\
\text { saja di Kodomain } \\
\text { (Ya/Tidak) }\end{array}$ \\
\hline 1 & $\{(1, a),(2, a),(2, b)\}$ & & \\
\hline 2 & $\{(1, b),(2, a),(2, b)\}$ & & \\
\hline 3 & $\{(1, a),(1, b),(3, b)\}$ & & \\
\hline 4 & $\{(2, a),(2, b),(3, a)\}$ & & \\
\hline 5 & $\{(2, a),(2, b),(2, c)\}$ & & \\
\hline 6 & $\{(1, b),(2, a),(2, b)\}$ & & \\
\hline 7 & $\{(3, a),(3, b),(3, c)\}$ & & \\
\hline 8 & $\{(1, b),(2, a),(3, b)\}$ & & \\
\hline
\end{tabular}

(b)

Gambar 5. Kesalahan Konsep Contoh Bukan Fungsi

Kesalahan konsep keenam terdapat pada halaman 108 soal nomor 5 (Gambar 6). Pada informasi disebutkan bahwa fungsi $\mathrm{n}$ dari himpunan $\mathrm{R}$ ke himpunan $\mathrm{R}$. Sementara pertanyaanya adalah pasangan berurutan, diagram panah dan tabel. Harusnya dikasih informasi lebih pada pertanyaan bahwa yang akan dicari (pasangan berurutan, diagram panah dan tabel) dalam bentuk diskrit bukan kontinu. 
Fungsi $n$ dari himpunan bilangan real $R$ ke himpunan bilangan real $R$ didefinisikan dengan grafik sebagai berikut.

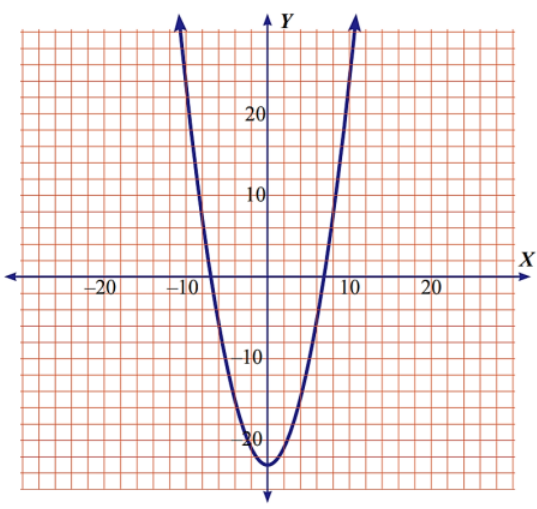

Nyatakan fungsi di atas dengan cara:

a. pasangan berurutan

b. diagram panah

c. tabel

Gambar 6. Kesalahan Konsep Data

Diskrit Menjadi Kontinu

b. Kesalahan Komputasi

Tidak ditemukan kesalahan komputasi pada materi relasi dan fungsi oleh peneliti.

c. Kesalahan Gambar

Kesalahan pada gambar dijumpai pada halaman 106, yaitu tentang menggambar Grafik (Gambar 7). Informasi yang diketahui adalah himpunan $\mathrm{P}$ dan himpunan $\mathrm{Q}$ yang mana anggotanya adalah bilangan asli. Tetapi di grafik yang digambarkan garis yang merupakan represetasi dari data kontinu. Alternative penyelesaian dari masalah ini adalah cukup menggambar titik titik $(1,2),(2,4)$, $(3,6),(4,8)$, dan $(5,10)$ pada diagram kartesius berupa titik titik tanpa dihubungkan oleh suatu garis.

\begin{tabular}{|c|c|c|c|c|c|}
\hline$x$ & 1 & 2 & 3 & 4 & 5 \\
\hline$f(x)$ & 2 & 4 & 6 & 8 & 10 \\
\hline
\end{tabular}

Cara 5: Dengan grafik

Diketahui fungsi $f$ dari $P=\{1,2,3$, $4,5\}$ ke $Q=\{1,2,3,4,5,6,7,8,9$, $10\}$. Relasi yang didefinisikan adalah "setengah kali dari",

Relasi ini dapat dinyatakan dengan grafik, sebagai berikut.

Uraian di atas menunjukkan macammacam cara yang bisa digunakan untuk menyatakan fungsi dari himpunan $P$ ke himpunan $Q$.

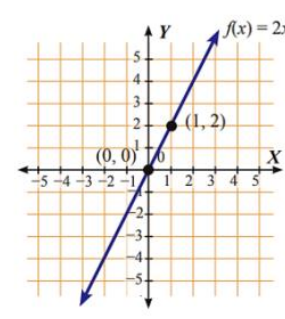

Gambar 7. Kesalahan Gambar Grafik Suatu Fungsi

Kesalahan gambar kedua terdapat pada halaman 115 no 12 (Gambar 8). Gambar nomor 12 itu bukan suatu fungsi, agar menjadi fungsi maka solusinya adalah dengan memutar grafik sejauh $90^{\circ}$. Selain itu pertanyaan juga harus diperjelas bahwa yang akan dicari adalah dalam bentuk diskrit bukan kontinu.

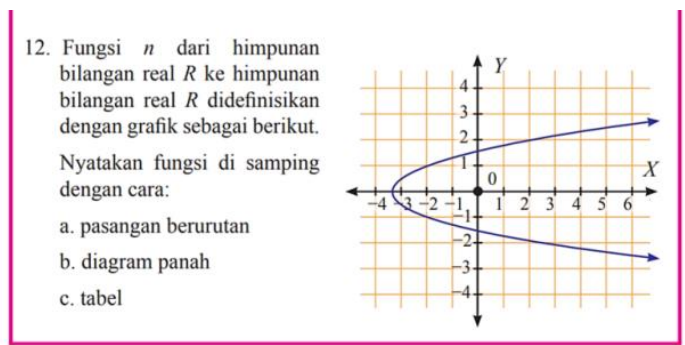

Gambar 8. Kesalahan Gambar Grafik Fungsi

d. Kesalahan Penulisan

Enam kesalahan penulisan yang pertama terjadi pada halaman 81 (Tabel 3.2 disebutkan Tabel 3.1), halaman 85 (Taufik ditulis Rahmad, Erik ditulis Herman dan Zainul ditulis 
Zaini), halaman 93 (sekedar ditulis sekadar dan seksama ditulis saksama). Pada halaman 100 (diawal dituliskan fungsi $\mathrm{B}$ ke A tetapi selanjutnya dituliskan fungsi A ke B). Halaman 102 (sub bab 3.2 membahas materi memahami ciri ciri fungsi, tetapi pada halaman ini disebutkan penyajian fungsi. Seharusnya penyajian fungsi akan lebih tepat dimasukan ke kegiatan 3.3 yaitu memahami bentuk penyajian fungsi). Halaman 103 ( soal nomor 7 dan 10 latihan soal sub bab 2 tentang relasi, akan lebih tepat jika dimasukan ke latihan soal subbab 3.1, yaitu tentang relasi) karena sub bab 2 membahas tentang ciri ciri fungsi. Selain itu terdapat salah ketik pada soal nomor 9 di halaman 103. Diketahui himpunan $\mathrm{K}$ dan $\mathrm{L}$ sedangkan yang ditanyakan himpunan A dan B. Alternative penyelesian dari masalah ini yaitu dengan mengganti himpunan A dan B menjadi himpunan $\mathrm{K}$ dan L. Halaman 112 salah penulisan diketahui ditulis diketaui, halaman 115 soal nomor 11 adalah soal tentang banyak pemetaan. Soal ini akan lebih tepat jika dimasukan pada latihan soal 3.2 yaitu tentang fungsi (pemetaan). Dan terakhir pada halaman 115 no 15 adalah soal tentang fungsi yang akan lebih tepat jika dimasukan pada latihan soal 3.2.

Tabel 3.2 Data pelajaran yang disukai siswa kelas VIII
\begin{tabular}{|l|l|}
\hline \multicolumn{1}{|c|}{ Nama Siswa } & \multicolumn{1}{c|}{ Pelajaran yang Disukai } \\
\hline Abdul & Matematika, IPA \\
\hline Budi & IPA, IPS, Kesenian \\
\hline Candra & Olahraga, Keterampilan \\
\hline Dini & Kesenian, Bahasa Inggris \\
\hline Elok & Matematika, IPA, Keterampilan \\
\hline
\end{tabular}

Permasalahan pada Tabel 3.1 di atas dapat dinyatakan dengan diagram panah, diagram Kartesius, dan himpunan pasangan berurutan seperti berikut ini.

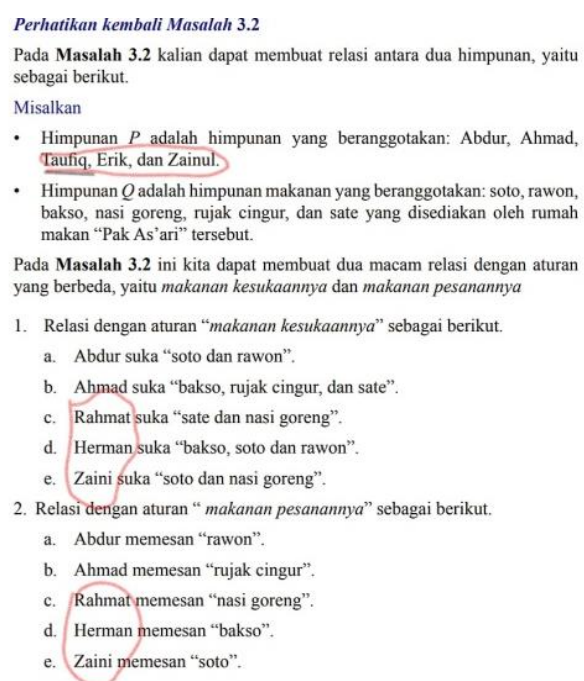

- Himpunan $Q$ adalah himpunan makanan yang beranggotakan: soto, rawon, bakso, nasi goreng, rujak cingur, dan sate yang disediakan oleh rumal makan "Pak As'ari" tersebut.

Pada Masalah 3.2 ini kita dapat membuat dua macam relasi dengan aturan yang berbeda, yaitu makanan kesukaannya dan makanan pesanannya

1. Relasi dengan aturan "makanan kesukaannya" sebagai berikut.

a. Abdur suka "soto dan rawon".

b. Ahmad suka "bakso, rujak cingur, dan sate".

c. Rahmat suka "sate dan nasi goreng".

d. Herman suka "bakso, soto dan rawon".

e. Zaini suka "soto dan nasi goreng".

2. Relasi dengan aturan " makanan pesanannya" sebagai berikut

a. Abdur memesan "rawon"

b. Ahmad memesan "rujak cingur".

c. Rahmat memesan "nasi goreng".

d. Herman memesan "bakso".

e. Zaini memesan "soto".

Aturan 1 sampai dengan aturan 4 pada Kegiatan 3.2 adalah relasi. Akan tetapi, aturan-aturan penyandian tersebut bukan hanya sekadar relasi. Aturan itu lebih tepat disebut sebagai fungsi dari himpunan $\{A, B, C, D, \ldots, Z\}$ ke himpunan $\{a, b, c, d, \ldots, z\}$, atau dari himpunan $\{A, B, C, D, \ldots, Z\}$ ke himpunan $\{0,1,2,3,4,5,6,7,8,9\}$, atau dari himpunan $\{A, B, C, D, \ldots, Z\}$ ke himpunan $\{a, b, c, d\}$.

Untuk memahami konsep fungsi, perhatikan dengan saksama kasus-kasus berikut. 
Tuliskan simpulan kalian pada lembar pengamatan kalian.

Sekarang coba kalian terapkan simpulan tersebut untuk memeriksa apakah himpunan pasangan berurutan berikut merupakan fungsi dari himpunan $B=\{a, b\}$ ke himpunan $A=\{p, q, r, s\}$ atau tidak?

1. $\{(a, p),(b, p)\}$

2. $\{(a, p),(b, q)\}$

3. $\{(a, p),(b, r)\}$

4. $\{(a, q),(b, s)\}$

5. $\{(a, q),(a, r)\}$

6. $\{(a, r),(b, r)\}$

7. $\{(b, s),(b, r),(a, p)\}$

8. $\{(a, p),(b, q),(a, r)\}$

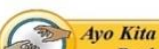

Tulislah simpulan kalian tentang ciri-ciri dari fungsi $A$ ke $B$, dan hasil pemeriksaan kalian terhadap 8 soal di atas.

Gambar 9. Kesalahan Penulisan

\section{SIMPULAN}

Hasil penelitian menunjukan bahwa buku matematika siswa pokok bahasan Relasi dan Fungsi kelas 8 semester I perlu adanya revisi karena masih ditemukan beberapa kesalahan. Kesalahan tersebut adalah kesalahan konsep, kesalahan gambar dan kesalahan penulisan. Kesalahan konsep yang ditemukan sebanyak 6 kesalahan. Kesalahan gambar sebanyak 2 kesalahan dan kesalahan penulisan sebanyak 15 kesalahan. Dari temuan ini, dapat dikatakan bahwa mutu buku ini belum optimal serta butuh terdapatnya revisi sehingga sejalan dengan tujuan dari pembuatan buku.

\section{DAFTAR PUSTAKA}

As'ari, Abdur Rohman dkk. 2017. Matematika SMP/MTs Kelas VIII Semester 1. Jakarta: Kementerian
Pendidikan dan Kebudayaan Republik Indonesia.

Kemdikbud. 2013. Pengembangan Kurikulum 2013. Paparan Kemdikbud dalam Sosialisasi Kurikulum 2013. Jakarta: Kemdikbud.

UM, W. D. P. (2020). Analisis kesalahan konsep persamaan kuadrat, fungsi kuadrat, dan pertidaksamaan kuadrat pada buku teks matematika SMA kelas $\mathrm{X}$ semester I/Makrip. SKRIPSI Mahasiswa UM.

Prastowo, A. (2013). Bahan Ajar Inovatif: Menciptakan Metode Pembelajaran yang Menarik dan Menyenangkan. Yogyakarta: Divapress.

Sitepu, B. P. (2012). Penulisan Buku Teks Pelajaran, Bandung: PT. Remaja Rosdakarya.

Susanto, B. (2012). ANALISIS KESALAHAN DAN PERBAIKAN KONSEP BUKU PELAJARAN MATEMATIKA SMP KELAS VIII TERBITAN PUSAT PERBUKUAN DEPARTEMEN PENDIDIKAN NASIONAL. 
Rohim, Analisis Kesalahan ...

Valentino, Erik. 2015.Analisis Kesalahan Buku Siswa Matematika Kelas VIII SMP/MTs Semester 1 Kurikulum 2013. Prosiding Seminar Nasional Matematika dan Pemelajarannya, hal 220-228. Malang: CV Bintang Sejahtera. 